\section{Social Media: A Breeding Ground for Energy or Apathy?}

\author{
Liana King
}

Sophomore, Communication and Social

Influence

\section{Introduction}

In this day and age, it is hard to imagine a facet of life free from the influence of social media. Fundamentally, social media serves as a platform for sharing and receiving information. From the breaking news of an earthquake to the announcement of an engagement, social media is often among the first to know-sometimes even before those directly affected. With the click of a button, we can extend anything expressible with words, images, or video to a defined set of followers or even to the world. With the increased prevalence of social media, people have naturally developed a reliance on these services. Users expect these networks to provide them with not only a platform to receive information, but also one in which they can express their own thoughts, beliefs, and opinions about that material.

One of the best examples of this phenomenon is the relationship between social media and politics. Social networks (e.g. Facebook, Twitter) have become fundamental to informing citizens about political issues. Additionally, these networks have become common outlets for people to express their own political ideals, shed light on neglected controversies, call others to action, etc. When a political issue is at large, it is hard to avoid coming into contact with a number of corresponding posts. I have found this to be especially notable in the past year due to the increased political tension arising from the 2016 presidential election followed by the Trump presidency.

It is hard to deny that social media can play a significant and potentially beneficial role in political activism. The ability to spread information so quickly to such a broad audience allows the citizenry to be informed about important political issues and possibly even promote activism. Innovative concepts can spread and influence others, petitions can reach beyond geographic barriers, marginalized groups can unify for equality, and so on. The Arab Spring serves as a prime example of this-social media acted as a catalyst for revolution by providing a platform for communication and unification.

It is evident that social media can be empowering. . However, at what point does social media stop serving as a means to effect change? When, if ever, does it start serving as a means to justify to oneself that they are having a positive impact on the world-- even if they are not?

This made me reflect on my own (in)action. I feel as though I am a well-informed citizen who understands the issues of our society and what needs to change. However, since the 2016 presidential election, I have been reflecting on how little I actually do to bring about the change I want to see.

The purpose of my research is to find the effects of posting about political and social issues on social media on how politically active people see themselves. 
Does posting about political and social issues create a false sense of political activism that contributes to decreased political participation? I hypothesize that the act of posting about political and social issues on social media acts as a substitute for action, creating a false sense of political activism.

\section{Literature Review}

I am grounding my study in the theoretical framework of the narcotizing dysfunction theory. The theory, originally developed by Paul F. Lazarsfeld and Robert K. Merton in 1948, states a "vast supply of communications may elicit only a superficial concern with the problems of society, and this superficiality often cloaks mass apathy" (Lazarsfeld and Merton 239). Essentially, as more time is "devoted to reading and listening, a decreasing share is available for organized action" (Lazarsfeld and Merton 239). For example, in 1950, "often dramatic coverage of congressional hearings concerning organized crime didn't lead to widespread public demands for government action" because even "when media are effective at... calling attention to societal problems... the public may react by doing nothing" (Baran and Davis 119). Someone consuming a lot of information on issues can "congratulate himself on his lofty state of interest and information" while simultaneously "neglect[ing] to see that he has abstained from decision and action" (Lazarsfeld and Merton 239). While this person may still have "all sorts of ideas as to what should be done," he or she goes throughout their day without the pressing need to engage further (Lazarsfeld and Merton 239). This would lead to those people being under the impression that they are doing their part in society even though that may not be true. This idea can easily be translated to social media, which is a breeding ground for the intake and transmission of information by which people are allegedly being narcotized.

A paper published in 2016 examining the relationship between social media and the narcotizing dysfunction theory argues that posting about political issues "may give the social media users a false sense of accomplishment and serves as a self-satisfactory tool and narcotizes the participants" (Esitti 1025). The term slacktivism was introduced in this paper, a combination of the word 'activism' and 'slacker.' Esitti points out that real activism is suppressed when users can read and write posts, tweets, blogs, etc. and become apathetic to the issue rather than energized (1022). The concept that "internet and social media may cause participatory surveillance rather than political participation," would support my hypothesis that digital activity takes the place of real political participation (Esitti 1022).

"Click to Change: Optimism Despite Online Activism's Unmet Expectations," outlines the idea that slacktivism can lead to political participation that is heavily skewed toward online activity. The Occupy Wall Street movement presents one interesting example. In that movement, "a far greater proportion of members...participated through Facebook [74.3\%] than through marching $(49.3 \%)$ or visiting a camp 
(63.3\%)" (Budish 751). The general consensus was that "online support did not translate into offline action" (Budish 752). This lack of tangible participation is why some scholars have criticized social media in its ability to effect real change. Although Budish argues that social media can still have positive effects, the acknowledgement of the presence of slacktivism supports my hypothesis.

\section{Methodology}

To conduct my primary research, I created a survey using Google Forms. My main interest was to examine the connection between self-ranked political activeness and frequency of posting about political/social issues on social media as well as involvement with different forms of political "action." I defined political action as engagement with one of the following activities: contacting elected officials, volunteering, and protesting. Due to my expectations of receiving responses from a majority of students my age (17 at the time of the 2016 election), I did not include a question about voting. In hindsight, that was a mistake considering the unexpectedly broad range of ages seen in my responses. I began by brainstorming an array of potential questions and eventually narrowed it down to fifteen. Each question was either multiple choice, answered on a scale of 1-5 (with each end of the spectrum being defined), with one question being an optional short answer that provided each participant with the opportunity to list political action I had not included. My questions and potential responses were:
1. What age group are you in? (Multiple choices: under 18, 18-22, 23-30, 30+)

2. In general, how would you describe your views on most political issues? (Scale of 1-5 with a 1 being "Very conservative" and a 5 being "Very liberal")

3. How would you respond to the following statement? "I am a politically active person." (Scale of 1-5 with a 1 being "Strongly disagree" and a 5 being "Strongly Agree")

4. In your opinion, how important is it to be politically active? (Scale of 1-5 with a 1 being "Not important at all" and a 5 being "Very important")

5. On average, how often do you post about political/social issues on social media? (Multiple choices: 1 or more times a day, 1-3 times per week, 1-3 times per month, 1-6 times per year, 0 times per year)

6. How would you respond to the following statement? "I believe being politically active on social media is a moral responsibility." (Scale of 1-5 with a 1 being "Strongly disagree" and a 5 being "Strongly agree")

7. In your opinion, do people post too much or too little about political/social issues on social media? (Multiple choices: Too much, Too little, The right amount)

8. When you post on social media about political/social issues, what is your primary purpose? (Multiple 
choices: To express your own views, To change the minds of others, To call others to specific actions (sign petitions, vote, etc.), I do not post about political issues on social media, Other (with a space to write in a unique answer))

9. How would you characterize the political views of your social media followers in relation to you? (Multiple choices: Mostly similar to me, Mostly different from me, Mixed)

10. How do you view the net impact of social media on society in terms of social and political issues? (Scale of $1-5$ with a 1 being "Very Harmful" and a 5 being "Very Beneficial")

11. How many hours per week do you spend reading about political or social issues you care about (in reputable sources)? (Multiple choices: Less than 1 hour, 1-3 hours, 3-6 hours, 6+ hours)

12. How many times in the past year have you contacted elected officials about issues you care about? (Multiple choices: Never, 1-3 times, 4-10 times, $10+$ times)

13. How many hours have you spent volunteering for political/social issues you care about in the past year (not including protesting)? (Multiple choices: No hours, 1-2 hours, 3-6 hours, $7+$ hours)

14. How many protests have you attended about political/social issues you care about in the past year?
(Multiple choices: None, 1-2, 3-6, $7+)$

15. If you have taken some other form of political action, please describe it here. (Optional short answer)

Once I had created my survey, I distributed it via text message and social media. I sent texts to friends and acquaintances from Temple as well as from my home in Washington, DC, asking them to take the survey and to send it along to their friends if they found it interesting. In my request to potential participants, I let them know that the survey was for a research project, but did not give any information regarding my hypothesis. In addition to the anonymity disclaimer on the survey itself, anonymity was promised in my request for people to take the survey. I then posted it to my Facebook page, which led to four more people sharing it on their feeds. Two of those shares were by other college students-- each attending a separate college other than Temple. The two other shares were by my mother (age 61) and brother (age 22).

Once I reached 160 completed surveys, I disabled the Google Form from accepting any more responses in order to begin analyzing my results. Google Forms provided me with a general understanding of responses to each individual question. However, it did not provide a way to analyze the connections between two responses and find patterns within the data. To do that, I had Google Forms turn my results into a Google Slides spreadsheet. From there, I decided the most effective way 
to analyze the data would be to create graphs. I did this by creating pivot tables, each of which compared two different sets of data (e.g. comparing self-ranked political activeness with frequency of political social media posting). From the pivot tables, I created $100 \%$ stacked column charts, which displayed data in terms of percentages. Through these graphs, I was able to observe the patterns in my data.

It is important to note the flaws in the distribution of my survey which could have led to skewed results. Most of my friends whom I reached out to share similar political beliefs, which is relevant because of the higher volume of social issues that liberals are typically concerned with (in comparison to conservatives). The fact that many of my friends are from Washington, $\mathrm{DC}$ is also relevant to a potential skew in my data because we grew up surrounded by politics, which could contribute to a higher sense of political activity. Additionally, because of the large role social media played in the distribution of my survey, it excluded potential responders who did not have social media. This could have also resulted in more active social media users to be exposed to my survey, which could have meant I had an unrealistically large portion of surveyors who post a lot on social media.

\section{Results}

Participants: 160
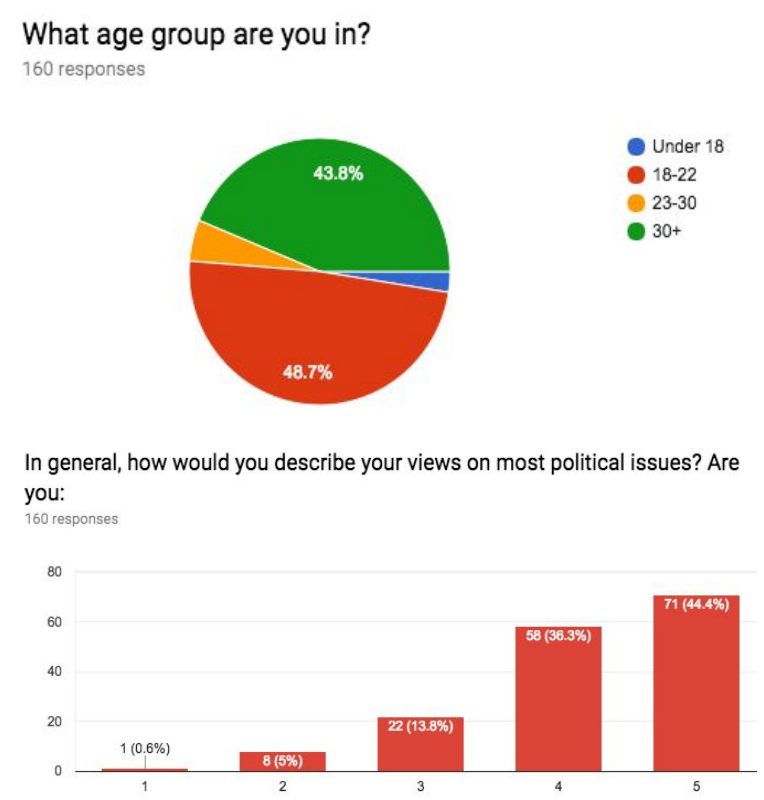

Raw Data:

As percentages of 160 :

1. How would you respond to the following statement? "I am a politically active person." (Scale of $1-5$ with a 1 being "Strongly disagree" and a 5 being "Strongly Agree")

$$
\text { 1: } \mathbf{2 . 5 \%}, 2: \mathbf{1 3 . 8 \%}, 3: \mathbf{2 5 . 6 \%}, 4 \text { : }
$$

43.1\%, 5: $15 \%$

2. In your opinion, how important is it to be politically active? (Scale of 1-5 with a 1 being "Not important at all" and a 5 being "Very important") 1: $\mathbf{0 \%}, 2: \mathbf{2 . 5 \%}, 3: \mathbf{1 5 \%}, 4: \mathbf{3 8 . 1 \%}$,

\section{5: $\mathbf{4 4 . 4 \%}$}

3. On average, how often do you post about political/social issues on social media? (Multiple choices: 1 or more times a day, 1-3 times per week, 1-3 times per month, 1-6 times per year, 0 times per year) 
1 or more times a day: $\mathbf{8 . 2 \%}, 1-3$ times per week: $\mathbf{2 0 . 3 \%}, 1-3$ times per month: $\mathbf{2 0 . 3 \%}$,

1-6 times per year: $\mathbf{2 8 . 5 \%}, 0$ times per year: $\mathbf{2 2 . 8 \%}$

4. How would you respond to the following statement? "I believe being politically active on social media is a moral responsibility." (Scale of 1-5 with a 1 being "Strongly disagree" and a 5 being "Strongly agree")

1: $\mathbf{2 1 . 9 \%}, 2: \mathbf{2 1 . 9 \%}, 3: \mathbf{3 4 . 4 \%}, 4$ :

$13.8 \%, 5: 8.8 \%$

5. In your opinion, do people post too much or too little about political/social issues on social media? (Multiple choices: Too much, Too little, The right amount) Too much: $\mathbf{3 7 . 5 \%}$, Too little: $\mathbf{2 0 \%}$, The right amount: $\mathbf{4 2 . 5 \%}$

6. When you post on social media about political/social issues, what is your primary purpose? (Multiple choices: To express your own views, To change the minds of others, To call others to specific actions (sign petitions, vote, etc.), I do not post about political issues on social media, Other (with a space to write in a unique answer))

To express your own views: $\mathbf{3 5 \%}$, To change the minds of others: $\mathbf{7 . 5 \%}$, To call others to specific actions (sign petitions, vote, etc.):

$\mathbf{2 3 . 1 \%}$, I do not post about political issues on social media: $\mathbf{2 3 . 1 \%}$, To spread awareness (several responses from the "other" category were phrased in different ways but I interpreted them all to mean this): $\mathbf{5 \%}$, informing others; appearing "woke;" and eliciting discussion; combinations of all categories: $\mathbf{6 . 3 \%}$

7. How would you characterize the political views of your social media followers in relation to you? (Multiple choices: Mostly similar to me, Mostly different from me, Mixed)

Mostly similar to me: $\mathbf{5 7 . 2 \%}$, Mostly different from me: $\mathbf{0 \%}$, Mixed: $\mathbf{4 7 . 8 \%}$

8. How do you view the net impact of social media on society in terms of social and political issues? (Scale of $1-5$ with a 1 being "Very Harmful" and a 5 being "Very Beneficial") 1: $\mathbf{5 . 6 \%}, 2: \mathbf{2 0 \%}, 3: \mathbf{5 0 . 6 \%}, 4$ :

$16.3 \%, 5: 7.5 \%$

9. How many hours per week do you spend reading about political or social issues you care about (in reputable sources)? (Multiple choices: Less than 1 hour, 1-3 hours, 3-6 hours, $6+$ hours)

Less than 1 hour: $\mathbf{1 2 . 5 \%}, 1-3$ hours: 38.1\%, 3-6 hours: 33.1\%, $6+$ hours: 16.2\%

10 . How many times in the past year have you contacted elected officials about issues you care about?

(Multiple choices: Never, 1-3 times, 4-10 times, $10+$ times)

Never: 35\%, 1-3 times: 38.1\%, 4-10

times: $\mathbf{1 4 . 4 \%}$, 10+ times: $\mathbf{1 2 . 5 \%}$

11. How many hours have you spent volunteering for political/social issues you care about in the past year (not including protesting)? (Multiple 
choices: No hours, 1-2 hours, 3-6

hours, $7+$ hours)

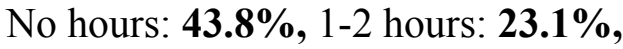
3-6 hours: $\mathbf{1 5 . 6 \%}, 7+$ hours: $\mathbf{1 7 . 5 \%}$

12. How many protests have you attended about political/social issues you care about in the past year? (Multiple choices: None, 1-2, 3-6, $7+$ )

None: $\mathbf{3 6 . 9 \%}, 1-2: \mathbf{3 4 . 4 \%}, 3-6$ :

\section{$\mathbf{2 4 . 4 \%}, 7+: \mathbf{4 . 4 \%}$}

13. If you have taken some other form of political action, please describe it here. (Optional short answer) Variety of responses summarized as: Making donations (8), attending meetings (2),

participating in political discussion/dialogue (4), voted (2), canvasing (2), Politically relevant art (1)

\section{Correlational Data:}

*It is important to note that the following graphs show percentages of the total responses and do not represent the different numbers of responses for each political activeness ranking. These graphs simply show patterns in the data.*
Social Media Posts in Relation to "Political Activeness"

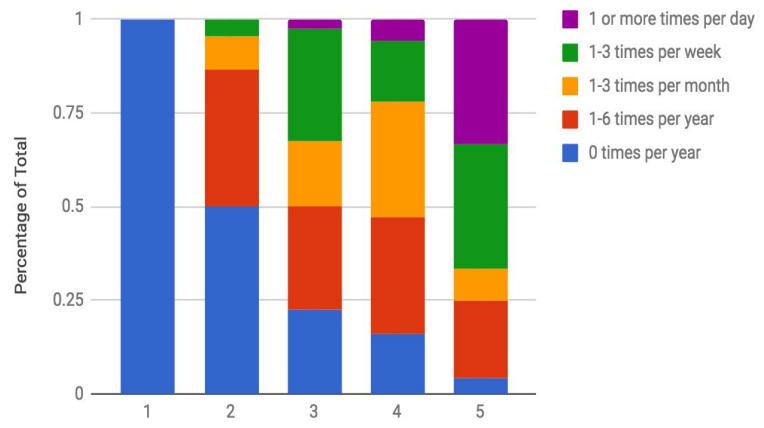

Self-Ranked Political Activeness

Hours Per Week Reading About Issues Cared About

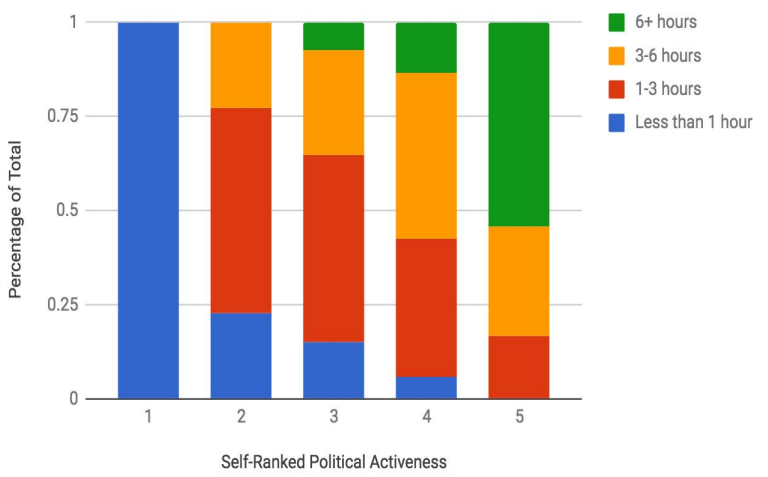

Moral Responsibility of Posting on Social Media to Frequency of Posting

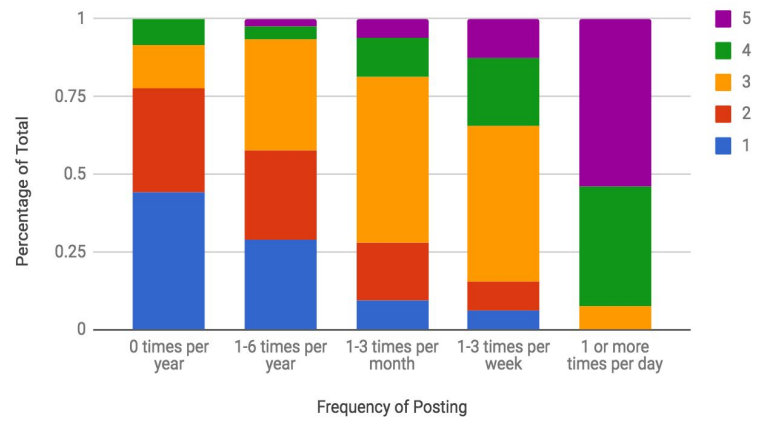

Self-Assessed Benefits of Social Media in Relation to Posting

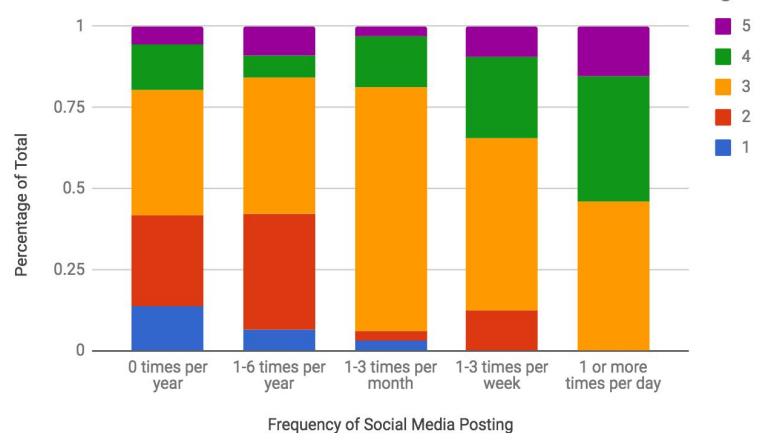




\begin{tabular}{|l|l|c|}
\hline $\begin{array}{c}\text { Activity in the } \\
\text { past year }\end{array}$ & $\begin{array}{l}\text { Those } \\
\text { who } \\
\text { ranked } \\
\text { themselve } \\
\text { s a 3 or } \\
\text { above in } \\
\text { political } \\
\text { activeness }\end{array}$ & $\begin{array}{l}\text { Those who } \\
\text { ranked } \\
\text { themselves } \\
\text { political } \\
\text { activeness }\end{array}$ \\
\hline $\begin{array}{l}\text { 0 hours } \\
\text { volunteering }\end{array}$ & $38 \%$ & $26 \%$ \\
\hline $\begin{array}{l}\text { Less than 3 } \\
\text { hours } \\
\text { volunteering }\end{array}$ & $60 \%$ & $49 \%$ \\
\hline $\begin{array}{l}\text { 0 elected } \\
\text { officials } \\
\text { contacted }\end{array}$ & $27 \%$ & $27 \%$ \\
\hline $\begin{array}{l}\text { Less than } 4 \\
\text { elected officials } \\
\text { contacted } \\
\text { protests }\end{array}$ & $67 \%$ & $61 \%$ \\
\hline Attended 0 & $68 \%$ & $62 \%$ \\
\hline than 3 protests & & \\
\hline
\end{tabular}

\begin{tabular}{|l|c|}
\hline $\begin{array}{l}\text { Spent more than } 7 \\
\text { hours volunteering }\end{array}$ & $28 \%$ \\
\hline $\begin{array}{l}\text { Contacted more } \\
\text { than } 4 \text { elected } \\
\text { officials }\end{array}$ & $38 \%$ \\
\hline $\begin{array}{l}\text { Contacted more } \\
\text { than } 10 \text { elected } \\
\text { officials }\end{array}$ & $18 \%$ \\
\hline $\begin{array}{l}\text { Attended more than } \\
3 \text { protests }\end{array}$ & $36 \%$ \\
\hline $\begin{array}{l}\text { Attended more than } \\
7 \text { protests }\end{array}$ & $5 \%$ \\
\hline
\end{tabular}

Other Relevant Data:

- Of my total 160 responses, $84 \%$ rated themselves a 3 or above in terms of political activeness and 58\% ranked themselves as a 4 or above.

- Of those who ranked themselves a 3 or above in political activeness, 55\% frequently post about political/social issues on social media

- Of those who ranked themselves a 4 or 5 in political activeness, $57 \%$ frequently post about political/social issues on social media

- Of those who ranked themselves a 5 in political activeness, $75 \%$

\begin{tabular}{|c|c|}
\hline $\begin{array}{c}\text { Activity in the past } \\
\text { year }\end{array}$ & $\begin{array}{l}\text { Those who ranked } \\
\text { themselves a } 4 \text { or } 5 \\
\text { in political } \\
\text { activeness }\end{array}$ \\
\hline $\begin{array}{l}\text { Spent more than } 3 \\
\text { hours volunteering }\end{array}$ & $51 \%$ \\
\hline
\end{tabular}
frequently post about political/social issues on social media

\section{Analysis}

A majority of people did consider themselves somewhat politically active (I interpreted a 3 or above to signify this) with 
more than half of my surveyors thinking of themselves as fairly politically active (I interpreted a 4 or 5 to signify this). People who thought of themselves as more politically active also tended to post more on social media and read more about political and social issues. Those who posted more on social media were more likely to view the act of posting (about political and social issues) as a moral responsibility. There was a slight relationship between posting more on social media and viewing the effects of social media on society as more beneficial. The most common purpose for posting on social media about political/social issues was to express one's own opinions. This is interesting, and might be connected to the fact that only $23.8 \%$ of people ranked the net impact of social media on society in terms of social and political issues as a 4 or 5. If much of the content is simply personal beliefs and opinions, it would be hard to garner much of a positive impact.

In the deeper analysis of the results based on my correlational data, I mainly paid attention to the patterns I found within the surveyors who selected a 3 or above and a 4 or above on the politically active scale. I chose to do so because the actions of people who disagreed that they were politically active were irrelevant to my research question.

In the pool of people who would consider themselves at least somewhat politically active ( 3 or above), more than a quarter had never contacted an elected official in the past year. I expected this number to shrink when I looked at how many 4's and 5's had contacted zero elected officials. Surprisingly, it was identical. So, even those who considered themselves in the top $2 / 5$ 's of political activeness still had more than a quarter of people never contact an elected official. Other surprising patterns I found were the high percentages of 3 's or above and 4's or above to have contacted less than 4 (this could include 0 ) elected officials. I interpreted this data to mean that even though people consider themselves politically active, a majority of them do not regularly contact elected officials, which is a relatively easy way to be politically involved. This could imply that contacting elected officials is not what everyone considers to be the trait of a politically active person. It could mean that people find justification for thinking of themselves as politically active from some other activity.

The high percentages of those ranking a 3 or above reporting to have spent 0 hours $(38 \%)$ or less than 3 hours $(60 \%)$ volunteering suggests that volunteering is also not an activity people associate with their own political activeness. The same seems to be true for those considering themselves slightly more politically active (ranked 4 or 5 ), with $26 \%$ spending 0 hours and $49 \%$ spending less than 3 hours. The fact that almost half of people who consider themselves politically active have given such little time to issues they care about may suggest that their perception of political activeness is not based in using their time to volunteer as much as other activity.

The same pattern was evident when looking at protests attended. $68 \%$ of those who ranked a 3 or above and $62 \%$ of those who ranked a 4 or above had attended less 
than 3 protests. Shockingly, 54\% of those who ranked themselves a 5 had attended less than 3 protests. Protesting also does not seem to be strongly correlated with perceived political activeness.

These statistics all elicit the question: if contacting elected officials, volunteering, or protesting is not strongly correlated to self-ranked political activeness, then what is causing people to perceive themselves as politically active?

To answer this question, it could be valuable to examine the connection between self-ranked political activeness and frequency of posting on social media about political and social issues (from now on, I will refer to this as simply "posting [on social media]," and let it be implied that it is in regards to political and social issues). Of my five frequencies ( 1 or more times per day, 1-3 times per week, 1-3 times per month, 1-6 times per year, 0 times per year), I deemed "frequent posting" as being anywhere from 1 or more times a day to 1-3 times per month. Through my graphs, I observed that $55 \%$ of those who ranked themselves a 3 or above posted frequently and $57 \%$ of 4 's or above posted frequently. Interestingly, $75 \%$ of 5 's posted frequently. The increasing percentages indicates that there was a connection between posting on social media and perceived political activism in my sample.

If we strictly look at the behavior of 4's and 5's, the highest level of action is indeed posting on social media (57\%) and reading the news $(64 \%)$, which suggests that these two factors carry most weight when people reflect on their own political action.

\section{Conclusion}

Through my research, I concluded that social media may indeed play a role in narcotizing my sample. Although there was a slight correlation between self-ranked political activeness and participation in political action, a majority of people who considered themselves politically active still spent infrequent or no time taking part in protests, volunteering, or contacting elected officials. The rates in which people posted on social media and read the news were much higher, which I have interpreted as the main basis behind people perceiving themselves as politically active. It seems as though when people are spreading and consuming a lot of information about issues they care about, it acts as a substitution for action, which aligns exactly with the theory of narcotizing dysfunction. People may feel as though they have fulfilled their duties by taking part in this exchange of information and therefore deserve to view themselves as politically active. However, when looking at their behavior, there is a lack of action that requires effort beyond the passive act of posting on social media or being informed. These findings align with the literature I read about narcotizing dysfunction and social media's effects on political activism.

When looking at possible solutions to the problem of people substituting knowledge and posting for action, it is crucial to recognize the nuanced nature of this issue. While posting on social media and being knowledgeable about relevant political issues may narcotize people and lead to passivity, there are still great advantages. The answer cannot possibly be 
to get rid of the knowledge and posting that narcotizes people, because the media (in the form of news and social media) is a fundamental bedrock of democracy. We need the media to spread information, keep the citizenry informed, and spark engagement. So when addressing this issue, I believe the answer lies not in the platform itself, but the messages delivered through the platform.

If more political posts, articles, news stories, etc. contained specific calls to action and ways to get involved (e.g. links to contact a specific elected official or organizations that need volunteers), maybe there would be more pressure for people to take part in action rather than simply read and share. If media could find a way to hold people accountable and emphasize the distinction between political awareness and political activeness, we may get closer to a societal shift in active political participation.

Furthermore, being cognizant of the narcotizing dysfunction theory could lead to critical self-reflection. There is a present lack of awareness of the narcotizing effects of social media and news consumption, which eliminates potential thoughtfulness about what actions one takes beyond the digital realm. Being aware of the potential for an apathetic subconsciousness may create more motivation to take real action. If people started to put less weight into their social media activity and put that energy toward contacting elected officials, volunteering, etc., society would benefit.

A greater abundance of extensive research would also be beneficial in order to learn more about this phenomenon. When I conducted my secondary research for this paper, I found a lack of research-based evidence to support the narcotizing effects of social media. This scarcity of research means it is hard to know the broader implications of posting about political and social issues on social media. If more studies existed, they would create awareness of the issue and perhaps spark a necessary dialogue about the consequences of narcotizing dysfunction.

The broader implications of this issue on society may be extensive. With a decline of political participation in the United States, the rise of social media has the potential to be detrimental to our democracy. If social media is serving as a means to narcotize the population, it will only exacerbate the lack of political action. At this point in society, when a need for emphasis on political participation is high, the dangers of narcotization are even more significant. 


\section{REFERENCES}

Baran, Stanley J., and Dennis K. Davis. Mass communication theory: foundations, ferment, and future. Cengage Learning, 2014, ebookcentral.proquest.com/lib/templeuniv-ebooks/reader.action?docID $=3425925$.

Budish, Ryan Hal. "Click to Change: Optimism Despite Online Activism's Unmet Expectations." Emory International Law Review, 12 Oct. 2012. EbscoHost, http://web.a.ebscohost.com/ehost/detail/detail?vid=5\&sid=d69e08ac-1d9a-44c7-81f9-5a7b f54dd08a\%40sessionmgr4009\&bdata=JnNpdGU9ZWhvc3QtbGl2ZSZzY29wZT1zaXRl\# $\mathrm{db}=\operatorname{lgs} \& A N=88409965$.

Esitti, Sakir. "Narcotizing Effect of Social Media." Research Gate, 1 Apr. 2016, www.researchgate.net/publication/301685342_Narcotizing_Effect_of_Social_Media.

Lazarsfeld, Paul Felix, and Robert King Merton. Mass communication, popular taste and organized social action. Bobbs-Merrill, College Division, 1948. Semantic Scholar, pdfs.semanticscholar.org/50c6/e01e5e345853eab8bebec12b5d95b398f16a.pdf. 